\title{
The Effect of Hepatectomy on the Synthesis of
}

\section{5-Hydroxyvitamin $\mathrm{D}_{3}$}

\author{
E. B. Olson, Jr., J. C. Knutson, M. H. Bhattacharyya, and \\ H. F. DeLuCA
}

From the Department of Biochemistry, College of Agricultural and Life

Sciences, University of Wisconsin-Madison, Madison, Wisconsin 53706

\begin{abstract}
A B S T R A C T The metabolism of $\left[{ }^{3} \mathrm{H}\right]$ vitamin $\mathrm{D}_{3}$ in hepatectomized vitamin $\mathrm{D}$-deficient rats has been studied. Hepatectomy drastically disrupts vitamin $\mathrm{D}_{3}$ metabolism as revealed by prolonged high levels of $\left[{ }^{3} \mathrm{H}\right]$ vitamin $\mathrm{D}_{3}$ in the plasma compartment even $12 \mathrm{~h}$ after dose in contrast to sham-operated controls. Some conversion of $\left[{ }^{3} \mathrm{H}\right]$ vitamin $\mathrm{D}_{3}$ to $\left[{ }^{3} \mathrm{H}\right] 25$-hydroxyvitamin $\mathrm{D}_{3}$ was detected in hepatectomized rats, but the amount was small in spite of the high circulating levels of $\left[{ }^{3} \mathrm{H}\right]$ vitamin $D_{s}$. Since the liver initially takes up much of an administered dose in normal animals and the conversion of $\left[{ }^{3} \mathrm{H}\right]$ vitamin $\mathrm{D}_{3}$ to $\left[{ }^{3} \mathrm{H}\right] 25$-hydroxyvitamin $\mathrm{D}_{3}$ is small in hepatectomized rats in spite of high circulating $\left[{ }^{3} \mathrm{H}\right]$ vitamin $D_{3}$, it is concluded that the liver plays a major role in the metabolism of vitamin $D_{3}$ to 25-hydroxyvitamin Ds.
\end{abstract}

\section{INTRODUCTION}

The metabolic processes and chemical alterations necessary for vitamin $D$ to fulfill its role in regulating calcium homeostasis have been clarified dramatically by a series of discoveries made within the past decade. Several recent reviews serve as excellent sources for those interested in a complete discussion of vitamin $\mathrm{D}$ metabolism and mechanism of action (1-3).

Under, normal circumstances, only small amounts of unchanged vitamin $\mathrm{D}$ circulate in the bloodstream. Unneeded vitamin D appears to be either stored as the unchanged molecule in adipose tissue (4) or metabolized and excreted. Vitamin D needed to fulfill its physiologi-

Dr. Olson's present address is Department of Preventive Medicine, University of Wisconsin-Madison, Madison, Wis. 53705 ; Dr. Knutson's is Department of Biochemistry, University of Washington, Seattle, Wash. 98195; and Dr. Bhattacharyya's is Argonne National Laboratories, Argonne, III. 60439.

Received for publication 30 October 1975 and in revised form 12 January 1976. cal roles must first undergo chemical alteration. The initial, obligatory step in vitamin D metabolism is hydroxylation at carbon-25 on the side chain.

Normally, the majority of circulating vitamin $\mathrm{D}$ is initally taken up by the liver where it can be converted to 25-hydroxyvitamin $\mathrm{D}_{3}\left(25-\mathrm{OH}-\mathrm{D}_{3}\right) .{ }^{1}$ Fig. 1 is a summary of data from several sources (5-8); it graphically illustrates the time sequence of the metabolic pools of vitamin $\mathrm{D}_{3}$ in the liver and plasma of vitamin D-deficient rats after a single intravenous dose of radioactive vitamin $\mathrm{D}_{3}$. The initial rapid disappearance of ${ }^{3} \mathrm{H}$ from plasma corresponds with a large uptake of radioactivity by the liver. At approximately $2-4 \mathrm{~h}$, the disappearance of $\left[{ }^{3} \mathrm{H}\right]$ plasma is interrupted by a rebound in radioactivity which is associated with a drop in liver radioactivity. This rebound can be accounted for by the appearance of $25-\mathrm{OH}-\mathrm{D}_{3}$ in the plasma compartment.

Based on such data, Ponchon and DeLuca first postulated that the liver is the major site of vitamin $D_{3}$ conversion to $25-\mathrm{OH}-\mathrm{D}_{3}$ (5). Later, they showed that the isolation of the liver from the circulation of vitamin D-deficient rats almost completely eliminates their ability to produce $25-\mathrm{OH}-\mathrm{D}_{3}$ (6). However, the possibility of some liver participation in the production of the small amount of $25-\mathrm{OH}-\mathrm{D}_{3}$ found in the plasma could not be excluded, since the vascularly isolated livers were still able to accumulate approximately $10 \%$ of the $\left[{ }^{3} \mathrm{H}\right]$ vita$\min \mathrm{D}_{3}$ by $4 \mathrm{~h}$.

Subsequent in vivo and in vitro studies of the liver hydroxylase responsible for the formation of $25-\mathrm{OH}-\mathrm{D}_{3}$ (9-11) have strengthened the idea that the liver is the major, if not sole, site of $25-\mathrm{OH}-\mathrm{D}_{3}$ production, and through this function serves as the obligatory source of the precursor for production of metabolically active 1,25-dihydroxyvitamin $\mathrm{D}_{3}\left(1,25-[\mathrm{OH}]_{2} \mathrm{D}_{3}\right)$.

\footnotetext{
${ }^{1}$ Abbreviations used in this paper: $25-\mathrm{OH}-\mathrm{D}_{3}, 25$-hydroxyvitamin $\mathrm{D}_{3} ; 1,25-(\mathrm{OH})_{2} \mathrm{D}_{3}, 1,25$-dihydroxyvitamin $\mathrm{D}_{\mathbf{3}}$.
} 


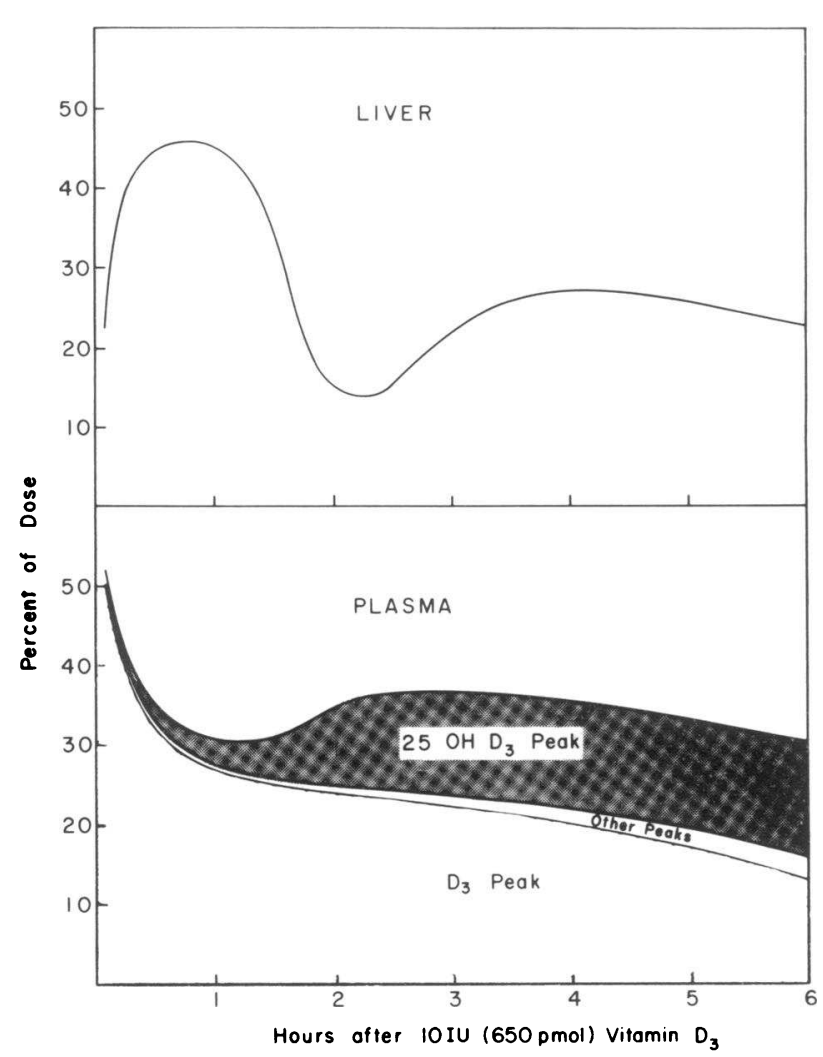

Figure 1 Liver and plasma radioactivity after an intrajugular injection of 10 IU $(650 \mathrm{pmol})$ of $\left[1,2-{ }^{3} \mathrm{H}\right]$ vitamin $\mathrm{D}_{3}$ into vitamin $\mathrm{D}$-deficient rats. These profiles are composites of data from several sources (5-8). The time-courses were smoothed through the use of weighted averages including values observed in successive 40 -min intervals. The plasma tritium was chromatographed and the fraction of the dose corresponding to unchanged vitamin $\mathrm{D}_{3}, 25-\mathrm{OH}-\mathrm{D}_{3}$, or other metabolites of vitamin $\mathrm{D}_{3}$ is indicated.

Recently the uniqueness of the liver's role in the 25hydroxylation of vitamin $\mathrm{D}$ has been challenged. Using the chick as a model for vitamin D metabolism, Tucker et al. (12) demonstrated that significant conversion of vitamin $\mathrm{D}_{3}$ to $25-\mathrm{OH}-\mathrm{D}_{3}$ occurs in homogenates from chick intestine and kidney as well as from chick liver. This would appear to conflict with the in vivo experiments of Ponchon et al. (6) which used hepatectomized rats. Assuming that the demonstration of 25-hydroxylation by intestine and kidney in vitro is correct, there remains the question of whether such conversion occurs in vivo. Although the experiments of Ponchon et al. (6) showed essentially no 25-hydroxylation by hepatectomized rats, these animals survived for only a 4-h period. Recently, Bollman and Van Hook have developed a technique for completely excising the liver from a living rat without compromising the intestinal venous drainage (13), which permitted much longer survival of rats. Using this technique, it has been possible to demonstrate that hepatectomized rats can convert vitamin $\mathrm{D}_{3}$ to $25-\mathrm{OH}-\mathrm{D}_{3}$. However, the amount is small and occurs in the face of high circulating levels of vitamin $D_{3}$. Additionally, hepatectomy greatly alters the course of vitamin $\mathrm{D}$ metabolism.

\section{METHODS}

20-day-old male Holtzman rats were fed a purified vitamin D-deficient diet $(0.47 \%$ calcium, $0.3 \%$ phosphorus $)$ supplemented with fat-soluble vitamins $\mathrm{A}, \mathrm{E}$, and $\mathrm{K}$ (14). After $1 \mathrm{wk}$ these rats weighed approximately $75 \mathrm{~g}$ and were used for the two-stage hepatectomy developed by Bollman and Van Hook (13). The first stage of this operation consists of ligating the inferior vena cava just proximal to the right renal vein and placing a cellophane band loosely around the portal vein. (A band of approximately 2-mm width was subjectively observed to produce less adhesions between the liver and duodenum than the originally recommended $5-\mathrm{mm}$ width band.) All experimental animals, including the shamoperated controls, underwent the first stage of the operation.

Over $45 \%$ (42 of 93 ) of these young rats recovered from surgery and survived on the vitamin D-deficient diet for an additional 6-8 wk. By this time these rats were deficient in vitamin $\mathrm{D}$, as evidenced by a lack of growth and low serum calcium levels, and their portal veins had become completely occluded with the development of sufficient collateral circulation to permit the second stage of the hepatectomy operation (13). All animals were fasted for $12 \mathrm{~h}$; for certain experiments, a number of the animals were given a $0.25-\mu \mathrm{g}$ (10 IU) dose of vitamin $D_{3}$ (gift of the Philips-Duphar Company of Amsterdam, The Netherlands) intrajugularly under light ether anesthesia $9 \mathrm{~h}$ before the second stage of the operation. Sham-operated controls were subjected to the same manipulations as required for removing the liver, except the sutures were placed and withdrawn without ligating vessels.

After the abdominal incision was closed, all experimental animals received an intrajugular dose of $\left[{ }^{3} \mathrm{H}\right]$ vitamin $\mathrm{D}_{3}$. (The $\left[1,2-{ }^{3} \mathrm{H}\right.$ ] vitamin $\mathrm{D}_{3}$ used [sp act $1,262 \mathrm{dpm} / \mathrm{pmol}$ ] was prepared according to the method of Neville and DeLuca [15].) The rats were then allowed to recover from the ether anesthesia and were maintained by frequent glucose administration. The tail vein cannulation recommended by Bollman and Van Hook (13) was not used; instead, all the rats (experimental and sham operated) were given an initial $2.5-\mathrm{ml}$ intraperitoneal injection of $10 \%$ glucose followed by $1.0-\mathrm{ml}$ hourly injections. This regimen of glucose administration was adequate for maintaining the hepatectomized rats for up to a 12-h experimental period. Those rats that failed to survive for the entire experimental period died due to bleeding or complications, which at autopsy could be directly related to surgical technique and not to hypoglycemia. The percentage of hepatectomy survivors steadily increased as the required surgical procedures were mastered.

At the end of the maintenance period the experimental rats were sacrificed by decapitation. The exposed blood vessels were heparinized and as much blood as possible was collected in a heparinized centrifuge tube. As indicated, appropriate organs were dissected out and stored frozen at $-20^{\circ} \mathrm{C}$ until used for analysis. Tissue lipids were extracted using the modified Bligh and Dyer (16) method described by Lund and DeLuca (17). An aliquot of the extract was counted and the remainder was dissolved in $65: 35$ chloroform-Skellysolve B (Skelly Oil Co., Kansas City, Mo.) and 
applied to a glass column $(1 \times 60 \mathrm{~cm})$ containing $15 \mathrm{~g}$ of Sephadex LH-20 according to the procedure of Holick and DeLuca (18). An aliquot from each fraction collected from these columns was dried in $15 \times 45-\mathrm{mm}$ glass vial inserts with a stream of air, dissolved in $4 \mathrm{ml}$ of toluene counting solution ( $2 \mathrm{~g}$ of PPO and $0.1 \mathrm{~g}$ of POPOP per 1 liter of toluene), and counted in a Packard Tri-Carb model 3375 liquid scintillation counter (Packard Instrument Co., Inc., Downers Grove, IIl). In some cases the fractions collected in the $25-\mathrm{OH}-\mathrm{D}_{3}$ region of the $\mathrm{LH}-20$ profile were pooled and subjected to co-chromatography with $\left[26,27-{ }^{14} \mathrm{C}\right] 25-\mathrm{OH}-$ $\mathrm{D}_{\mathrm{s}}$ (synthesized in this laboratory by M. F. Holick) on hydroxyalkoxypropyl Sephadex as described by Jones et al. (19). The hydroxyalkoxypropyl Sephadex used had a 55\% hydroxyalkyl group content and was prepared in this laboratory by G. Jones using Nedox 1518 (a gift from Ashland Chemical Co., Columbus, Ohio), according to the method described by Ellingboe et al. (20). Total disintegrations of ${ }^{3} \mathrm{H}$ (and ${ }^{14} \mathrm{C}$ where applicable) were determined through routine use of an automatic external standard and a computer program correcting for efficiency, channel spillover, and background radiation. Plasma extract results are expressed as the percent of the original $\left[{ }^{3} \mathrm{H}\right]$ vitamin $\mathrm{D}_{3}$ dose, assuming that plasma comprises $3.0 \%$ of the total body weight. In all cases, hematocrits of experimental and control animals remained within normal limits.

\section{RESULTS}

Using the described protocol we achieved approximately $30 \%(26 / 88)$ success in producing hepatectomized vitamin D-deficient rats. $54 \%(14 / 26)$ of these rats recovered and survived without a liver until sacrificed 4, 6, or $12 \mathrm{~h}$ later. In addition, five vitamin $\mathrm{D}$-deficient rats, which had recovered from the first stage of the operation, were used as sham-operated controls. Four of these survived until sacrificed.

$6 \mathrm{~h}$ after hepatectomized rats received an intrajugular dose of $10 \mathrm{IU}(650 \mathrm{pmol})\left[{ }^{3} \mathrm{H}\right]$ vitamin $\mathrm{D}_{3}$, approximately $50 \%$ of the ${ }^{3} \mathrm{H}$ remained in the plasma compartment. A composite profile of the Sephadex LH-20 chromatography of the plasma extract is shown in Fig. 2B. $1.4 \%$ of the administered radioactivity chromatographed in the same region as $25-\mathrm{OH}-\mathrm{D}_{3}$, and $49.1 \%$ chromatographed in the same region as unchanged vitamin $\mathrm{D}_{3}$.

The fact that over $50 \%$ of the initial vitamin $\mathrm{D}_{3}$ dose is in the plasma compartment of hepatectomized rats after $6 \mathrm{~h}$ indicates that the rat without a liver does not remove vitamin $D_{3}$ from its blood very efficiently. An overview of the overall disappearance of a $10-$ IU intravenous dose of vitamin $\mathrm{D}_{3}$ in vitamin $\mathrm{D}$-deficient rats without a liver is shown in Fig. 2. The Sephadex LH-20 profile of the plasma extract from a hepatectomized rat $6 \mathrm{~h}$ after an intrajugular dose of 10 -IU vitamin $\mathrm{D}_{3}$ (Fig. 2B) is compared with the profiles 4 and $12 \mathrm{~h}$ after a similar dose. Notice that at $12 \mathrm{~h}$ (Fig. 2C) over $30 \%$ of the original radioactivity remains in the plasma in a peak which chromatographs in the same region as unchanged vitamin $\mathrm{D}_{3}$, while $1.5 \%$ of the original radioactivity in the plasma chromatographs similarly to 25$\mathrm{OH}-\mathrm{D}_{3}$. After $4 \mathrm{~h}$ (Fig. 2A), approximately $80 \%$ of the

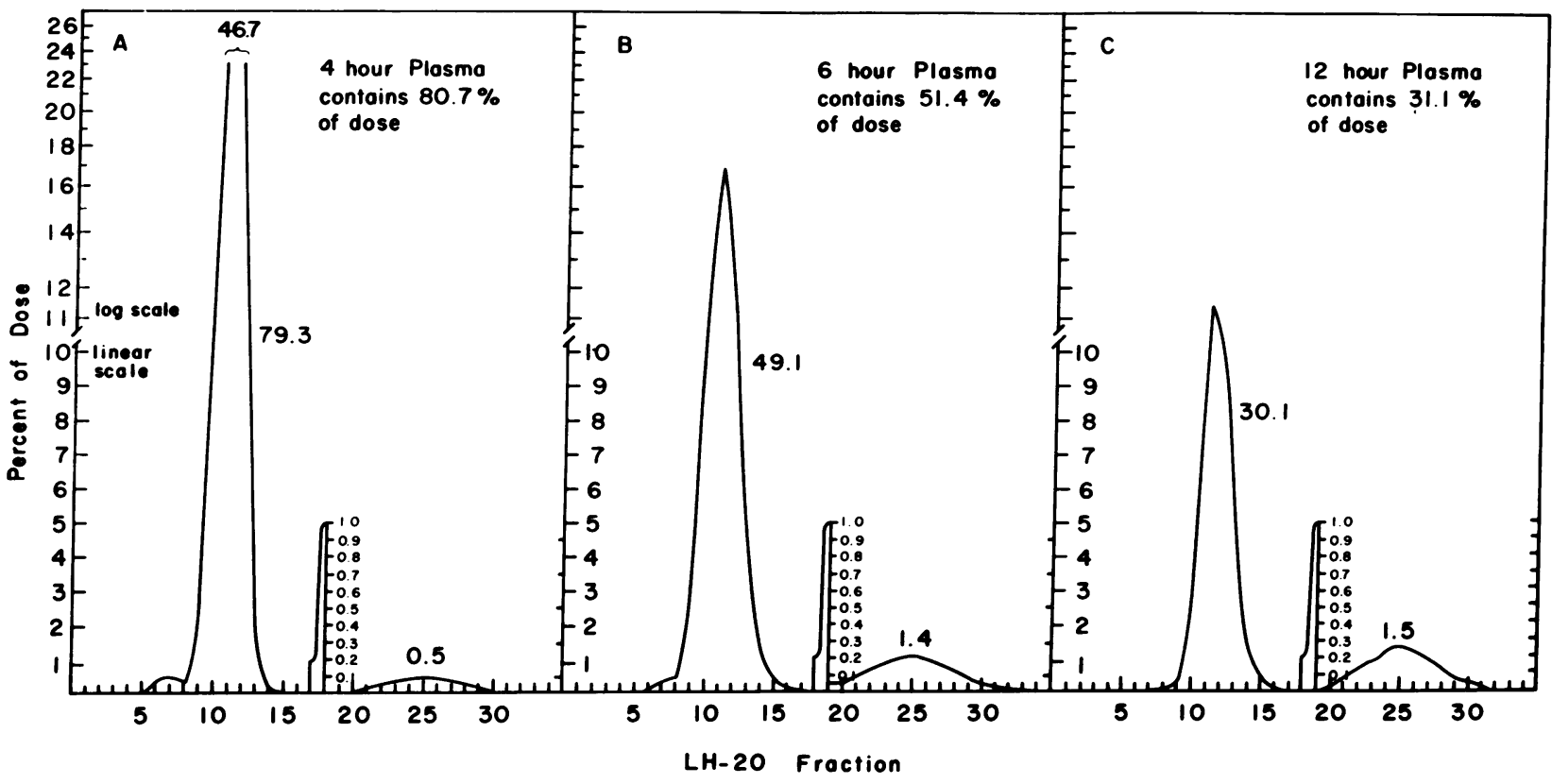

FIGURE 2 Sephadex LH-20 chromatographic profiles of tritium extracted from the plasma of vitamin $\mathrm{D}$-deficient rats at different times after hepatectomy and an intrajugular dose of $10 \mathrm{IU}$ $(650 \mathrm{pmol})$ of $\left[1,2-^{3} \mathrm{H}\right]$ vitamin $\mathrm{D}_{\mathrm{s}}$. (2A, A composite of data from three rats; $2 \mathrm{~B}$, two columns, one rat and a pool of two rats; $2 \mathrm{C}$, data from a single rat.) 
administered vitamin $\mathrm{D}_{3}$ remains in the plasma compartment of hepatectomized, vitamin $\mathrm{D}$-deficient rats. The great majority of this plasma radioactivity appears to be unchanged vitamin $D_{3}$. Approximately $0.5 \%$ of the original $10 \mathrm{IU}$ ( $650 \mathrm{pmol})$ of vitamin $\mathrm{D}_{\mathbf{3}}$ has been converted to a $25-\mathrm{OH}-\mathrm{D}_{3}$-like metabolite.

Because in the previous experiment the tissues were exposed to high concentrations of $\left[{ }^{3} \mathrm{H}\right]$ vitamin $\mathrm{D}_{3}$ for long periods, the dose of $\left[{ }^{3} \mathrm{H}\right]$ vitamin $\mathrm{D}_{3}$ to hepatectomized rats was reduced to $6.5 \mathrm{IU}$. Table I presents a comparison of the data obtained with sham-operated rats and hepatectomized rats $6 \mathrm{~h}$ after the indicated dose of $\left[{ }^{8} \mathrm{H}\right]$ vitamin $D_{3}$. The percentage of the dose circulating as vitamin $\mathrm{D}_{3}$ is not changed by reducing the dose of $\left[{ }^{3} \mathrm{H}\right]$ vitamin $\mathrm{D}_{8}$ from 10 to $6.5 \mathrm{IU}$. Thus, the actual amount of circulating vitamin $\mathrm{D}_{3}$ is reduced from 319.2 to 185.5 pmol simply by reducing the dose of vitamin $\mathrm{D}_{8}$ from 10 to $6.5 \mathrm{IU}$. However, this reduced level of circulating vitamin $D_{3}$ is still over twice the level of vitamin $D_{3}$ circulating in intact rats at $6 \mathrm{~h}$ after dose.

Interestingly, the reduction in the amount of circulating vitamin $D_{3}$ achieved by reducing the initial vitamin $D_{s}$ dose does reduce the amount of circulating 25-

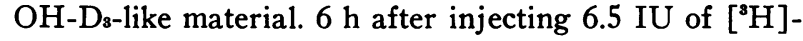
vitamin $\mathrm{D}_{3}$ into hepatectomized rats, $0.9 \%$ of the dose or $3.8 \mathrm{pmol}$ is circulating as a $25-\mathrm{OH}-\mathrm{D}_{3}$-like metabolite. In contrast, the $10-\mathrm{IU}$ dose produces a $25-\mathrm{OH}-\mathrm{D}_{3}$ peak which contains $9.1 \mathrm{pmol}$ or $1.4 \%$ of the original dose.

The effects of removing the liver on vitamin $\mathrm{D}$ metabolite accumulation by kidney and small intestine com- pared to the plasma metabolites are shown in Table II. $6 \mathrm{~h}$ after a 10-IU intrajugular dose of $\left[{ }^{3} \mathrm{H}\right]$ vitamin $\mathrm{D}_{3}$, a sham-operated rat had $4.6 \%$ of the dose circulating in the plasma as $25-\mathrm{OH}-\mathrm{D}_{3}$-like material and $0.4 \%$ of the dose as $1,25-(\mathrm{OH})_{2} \mathrm{D}_{3}$-like material. In the same rat, the kidneys and small intestine had also accumulated significant amounts of unchanged vitamin $\mathrm{D}_{3}, 25-\mathrm{OH}-\mathrm{D}_{3}$, and $1,25-(\mathrm{OH})_{2} \mathrm{D}_{3}$-like material. In contrast to this, a hepatectomized rat which has an elevated circulating level of unchanged vitamin $D_{3}$ and a small amount of circulating 25-OH-Ds-like material had no detectable $1,25-(\mathrm{OH})_{2} \mathrm{D}_{3}$ in its plasma, kidneys, or small intestine and very reduced levels of $25-\mathrm{OH}_{-} \mathrm{D}_{3}$-like material in its kidney or small intestine compared to the sham-operated control. Interestingly, the hepatectomized rat did accumulate unchanged vitamin $\mathrm{D}_{3}$ in its kidneys and small intestine.

The previous results (Fig. 2 and Tables I and II) indicate that in hepatectomized rats the normal sequence of vitamin $\mathrm{D}_{\mathbf{3}}$ metabolism is dramatically altered. In Fig. 3 the chromatographic profiles of plasma lipid extracts from sham-operated controls which had survived the alterations in visceral circulation produced by the first stage of the hepatectomy operations are illustrated. Both 6 and $12 \mathrm{~h}$ after an intrajugular dose of $10 \mathrm{IU}{ }^{3} \mathrm{H}$-vitamin $\mathrm{D}_{3}$, the vitamin $\mathrm{D}$-deficient rats which retained their livers (with a somewhat altered circulation) were able to approximate the normal vitamin $\mathrm{D}_{3}$ plasma metabolic pattern as summarized in Fig. 1. These rats clearly exhibited a more rapid reduction in circulating vitamin $\mathrm{D}_{3}$ and a greater production of 25 -

TABLE I

25-OH- $D_{3}$ Production at Varying Vitamin $D_{3}$ Levels

\begin{tabular}{|c|c|c|c|c|c|}
\hline & \multicolumn{4}{|c|}{ Dose } & \multirow{3}{*}{$D_{z} / 25-\mathrm{OH}-\mathrm{D}_{3}$} \\
\hline & \multicolumn{2}{|c|}{ Vitamin $D_{3}$ peak } & \multicolumn{2}{|c|}{ 25-OH-D\& peak } & \\
\hline & $\%$ & pmol & $\%$ & pmol & \\
\hline $\begin{array}{l}\text { Sham, } \\
\qquad 10 \mathrm{IU}\left[{ }^{3} \mathrm{H}\right] \mathrm{D}_{3}\end{array}$ & $\begin{array}{c}14.2 \\
(8.8-19.6)^{*}\end{array}$ & 92.3 & $\begin{array}{c}3.9 \\
(3.2-4.6)\end{array}$ & 25.4 & $\begin{array}{c}3.6 \\
(2.8-4.2)\end{array}$ \\
\hline $\begin{array}{l}\text { Hepatectomy, } \\
10 \mathrm{IU}\left[{ }^{3} \mathrm{H}\right] \mathrm{D}_{3}\end{array}$ & $\begin{array}{c}49.1 \\
(39.9-57.8)\end{array}$ & 319.2 & $\begin{array}{c}1.4 \\
(1.4-1.4)\end{array}$ & 9.1 & $\begin{array}{c}35.1 \\
(29.3-39.9)\end{array}$ \\
\hline $\begin{array}{l}\text { Hepatectomy, } \\
6.5 \mathrm{IU}\left[{ }^{3} \mathrm{H}\right] \mathrm{D}_{3}\end{array}$ & $\begin{array}{c}43.9 \\
(37.5-50.4)\end{array}$ & 185.5 & $\begin{array}{c}0.9 \\
(0.8-1.1)\end{array}$ & 3.8 & $\begin{array}{c}48.8 \\
(46.6-49.4)\end{array}$ \\
\hline
\end{tabular}

Unchanged vitamin $\mathrm{D}_{3}$ and $25-\mathrm{OH}-\mathrm{D}_{3}$ Sephadex LH-20 peaks from the plasma of vitamin $\mathrm{D}$ deficient rats with or without their livers $6 \mathrm{~h}$ after the indicated intrajugular dose of $\left[1,2-{ }^{3} \mathrm{H}\right]$ vitamin $\mathbf{D}_{\mathbf{3}}$. (Sham, composite of data from two rats; hepatectomy, composite of data from three rats; $6.5 \mathrm{IU}$ hepatectomy, composite of data from four rats).

* Values in parentheses, range. 
TABLE II

Accumulation of 25-OH- $\mathrm{D}_{3}$ and 1,25-(OH) ${ }_{2} \mathrm{D}_{3}$ in Tissues of Hepatectomized Rats

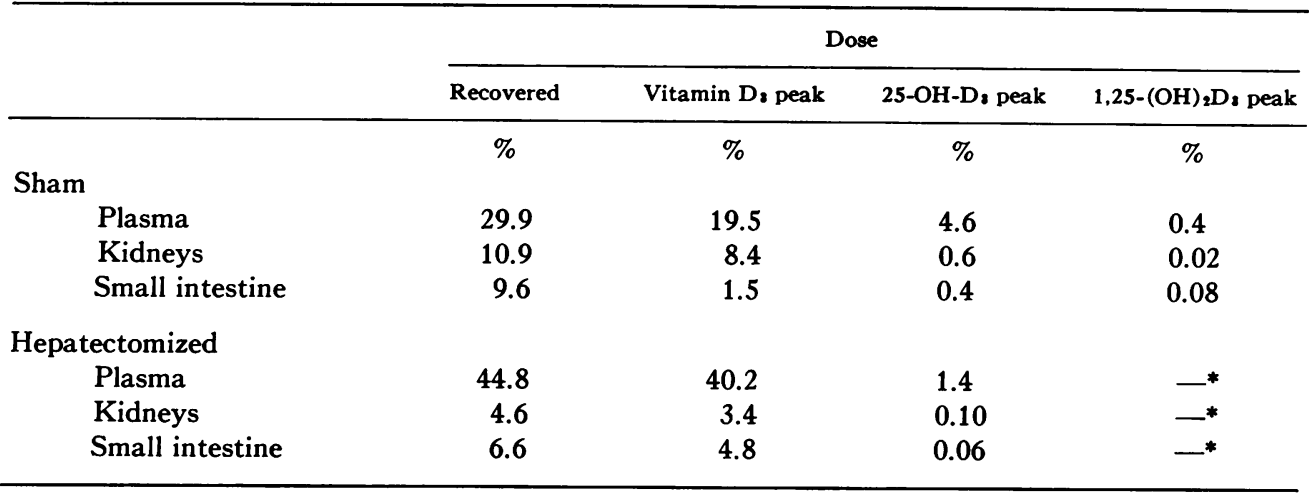

Analysis of the indicated tissue compartments from two vitamin D-deficient rats with or without their livers $6 \mathrm{~h}$ after a $10-\mathrm{U}(650 \mathrm{pmol})$ intrajugular dose of $\left[1,2-{ }^{\mathrm{d}} \mathrm{H}\right]$ vitamin $\mathrm{D}_{3}$.

* Undetectable.

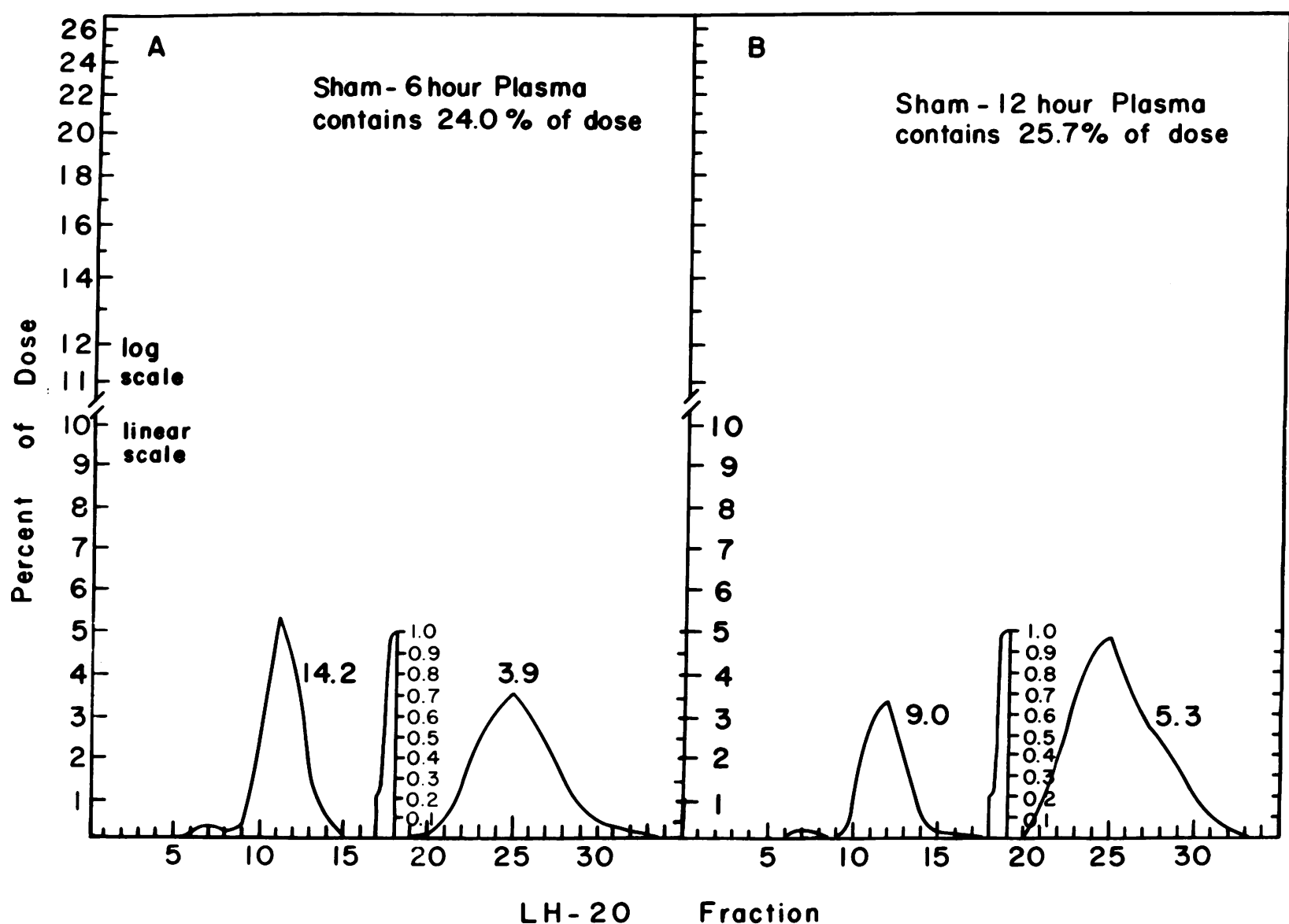

FIGURE 3 Sephadex LH-20 chromatographic profiles of tritium extracted from the plasma of vitamin D-deficient rats 6 or $12 \mathrm{~h}$ after a sham hepatectomy and an intrajugular dose of $10 \mathrm{IU}$ (650 pmol) of $\left[1,2-{ }^{3} \mathrm{H}\right]$ vitamin $\mathrm{D}_{3}$. (3A, A composite of data from two rats; $3 \mathrm{~B}$, data from a single rat.) 


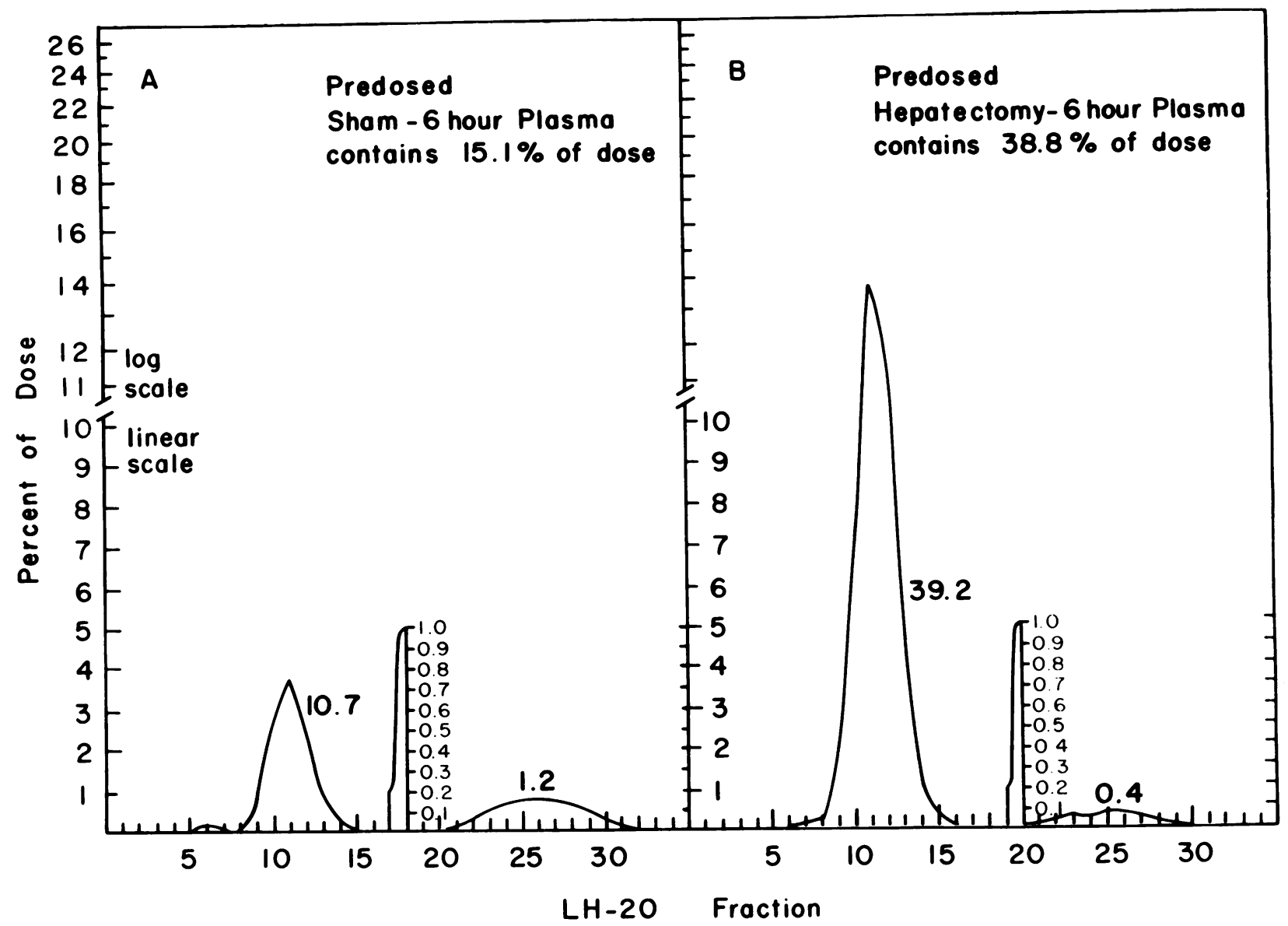

FIGURE 4 Sephadex LH-20 chromatographic profiles of tritium extracted from the plasma of vitamin D-deficient rats $6 \mathrm{~h}$ after the indicated liver operation and an intrajugular dose of 10 IU $(650 \mathrm{pmol})$ of $\left[1,2-{ }^{8} \mathrm{H}\right]$ vitamin $D_{3}$. The rats were given an intrajugular dose of $10 \mathrm{IU}$ (650 pmol) of nonradioactive vitamin $D_{3} 9 \mathrm{~h}$ before surgery. (4A, data from a single rat; $4 \mathrm{~B}$, a composite of data from two rats.)

$\mathrm{OH}-\mathrm{D}_{3}$-like material than the corresponding hepatectomized rats (Fig. $2 \mathrm{~B}$ and $\mathrm{C}$ ).

Vitamin D-deficient rats do appear to be able to produce a $25-\mathrm{OH}-\mathrm{D}_{3}$-like metabolite in the absence of their livers. Fig. 4 presents data which indicate that the production of a $25-\mathrm{OH}-\mathrm{D}_{3}$-like metabolite in hepatectomized rats is inhibited by a $10-\mathrm{IU}$ predose of unlabeled vitamin $\mathrm{D}_{\mathbf{3}}$ (compare Fig. 4B with Fig. 2B) just as it does to intact vitamin D-deficient animals (compare Fig. 4A with Fig. 3A). Thus, the 25-OH-D -like material produced by rats without a liver appears to be subject to feedback inhibition analogous to the previously studied hepatic vitamin $\mathrm{D}_{3}-25$-hydroxylase system $(10,11)$.

The vitamin $\mathrm{D}_{3}$ metabolite extracted from hepatectomized rat plasma which chromatographs like $25-\mathrm{OH}-\mathrm{D}_{3}$ on Sephadex LH-20 in part co-chromatographs with synthetically prepared ${ }^{14} \mathrm{C}$-labeled $25-\mathrm{OH}-\mathrm{D}_{3}$ on a hy- droxyalkoxypropyl Sephadex chromatographic system. Fig. 5 is a composite representative of two instances in which the tritium containing $25-\mathrm{OH}-\mathrm{D}_{3}$ metabolite, isolated after Sephadex LH-20 chromatography of hepatectomized rat plasma lipid extract, was combined with synthetically prepared ${ }^{14} \mathrm{C}$-labeled $25-\mathrm{OH}-\mathrm{D}_{3}$. Notice that over $84 \%$ of the ${ }^{14} \mathrm{C}$-labeled $25-\mathrm{OH}-\mathrm{D}_{3}$ was recovered in a symmetrical $25-\mathrm{OH}-\mathrm{D}_{3}$ peak. Approximately $58 \%$ of the tritium-containing metabolite obtained from Sephadex LH-20 chromatography co-chromatographs precisely with the known ${ }^{14} \mathrm{C}$-labeled $25-\mathrm{OH}-\mathrm{D}_{\mathbf{s}}$ peak. The remainder of the tritium was found in small amounts in the remaining fractions.

\section{DISCUSSION}

It is apparent that extrahepatic 25-hydroxylation of vitamin $D_{3}$ is possible, inasmuch as totally hepatectomized rats produce a metabolite from vitamin $\mathrm{D}_{s}$ which co- 
chromatographs with $\left[{ }^{14} \mathrm{C}\right] 25-\mathrm{OH}-\mathrm{D}_{3}$ on a column which has powerful resolving ability (19). However, the amount of $25-\mathrm{OH}-\mathrm{D}_{3}$ produced in hepatectomized rats is small in spite of high circulating levels of $\left[{ }^{3} \mathrm{H}\right]$ vitamin $D_{3}$. Reduction of the dose of $\left[{ }^{3} \mathrm{H}\right]$ vitamin $\mathrm{D}_{3}$ to the limit dictated by the specific activity of $\left[{ }^{3} \mathrm{H}\right]$ vitamin $\mathrm{D}_{3}$ reduced the amount of $\left[{ }^{3} \mathrm{H}\right] 25-\mathrm{OH}-\mathrm{D}_{3}$ appearing in the serum of hepatectomized rats. However, the circulating levels of $\left[{ }^{3} \mathrm{H}\right]$ vitamin $\mathrm{D}_{3}$ in this experiment were still very high relative to those in intact rats. Furthermore, almost half of the ${ }^{8} \mathrm{H}$ material which migrated as 25$\mathrm{OH}-\mathrm{D}_{3}$ on Sephadex LH-20 chromatography of the extracts from hepatectomized rats did not co-chromatograph with $25-\mathrm{OH}-\mathrm{D}_{3}$. This column, on the other hand, gave $85 \%$ recovery of standard $\left[{ }^{14} \mathrm{C}\right] 25-\mathrm{OH}-\mathrm{D}_{3}$, demonstrating that a significant amount of the 25-OH-D - like material from hepatectomized rats is not $25-\mathrm{OH}-\mathrm{D}_{3}$. Because the actual amount of $\left[{ }^{3} \mathrm{H}\right] 25-\mathrm{OH}-\mathrm{D}_{3}$ in serum which is derived from $\left[{ }^{3} \mathrm{H}\right]$ vitamin $\mathrm{D}_{3}$ in hepatectomy is very small even in the face of high circulating amounts of $\left[{ }^{3} \mathrm{H}\right]$ vitamin $\mathrm{D}_{3}$, we concluded that in the rat, extrahepatic production of $25-\mathrm{OH}-\mathrm{D}_{3}$ under physiological conditions is likely very small. This view is also supported by the fact that the liver initially accumulates much of the administered dose of vitamin $\mathrm{D}_{3}$ and that the vitamin $\mathrm{D}_{3}$ does not proceed to the extrahepatic tissues until 25-OH-Ds appears in the blood $(5-8,15)$. Thus, physiologically, the route of vitamin D metabolism must initially involve the liver.

That the liver plays an important role in vitamin D metabolism is strongly supported by the present results. In the absence of the liver vitamin $D_{3}$ persists for a long period of time in the vascular compartment. This contrasts with the rapid disappearance of vitamin $D_{3}$ from the plasma compartment in intact rats (5-8). It is not clear why adipose and other tissues do not rapidly take up the vitamin $D_{3}$ from the circulation in the absence of liver. It is possible that the liver plays an important role in the biogenesis of a transport protein of plasma which may play a role in tissue uptake. Another possibility is that the liver may play an important role in the association of vitamin $\mathrm{D}$ with the transport protein (21). Still another possibility is an enterohepatic circulation system (22). These possibilities all merit further investigation.

In the present study the possible appearance of 25$\mathrm{OH}-\mathrm{D}_{3}$ in small intestine and kidney was also examined. In the intact animal the expected pattern of 25-hydroxylation in the liver followed by 1-hydroxylation in the kidney is reflected in the appearance of circulating metabolites corresponding to 25-OH-D and $1,25-(\mathrm{OH})_{2} \mathrm{D}_{3}$ and the accumulation of these metabolites in target tissues. However, in the hepatectomized rat, even though there does appear to be a small amount of circulating

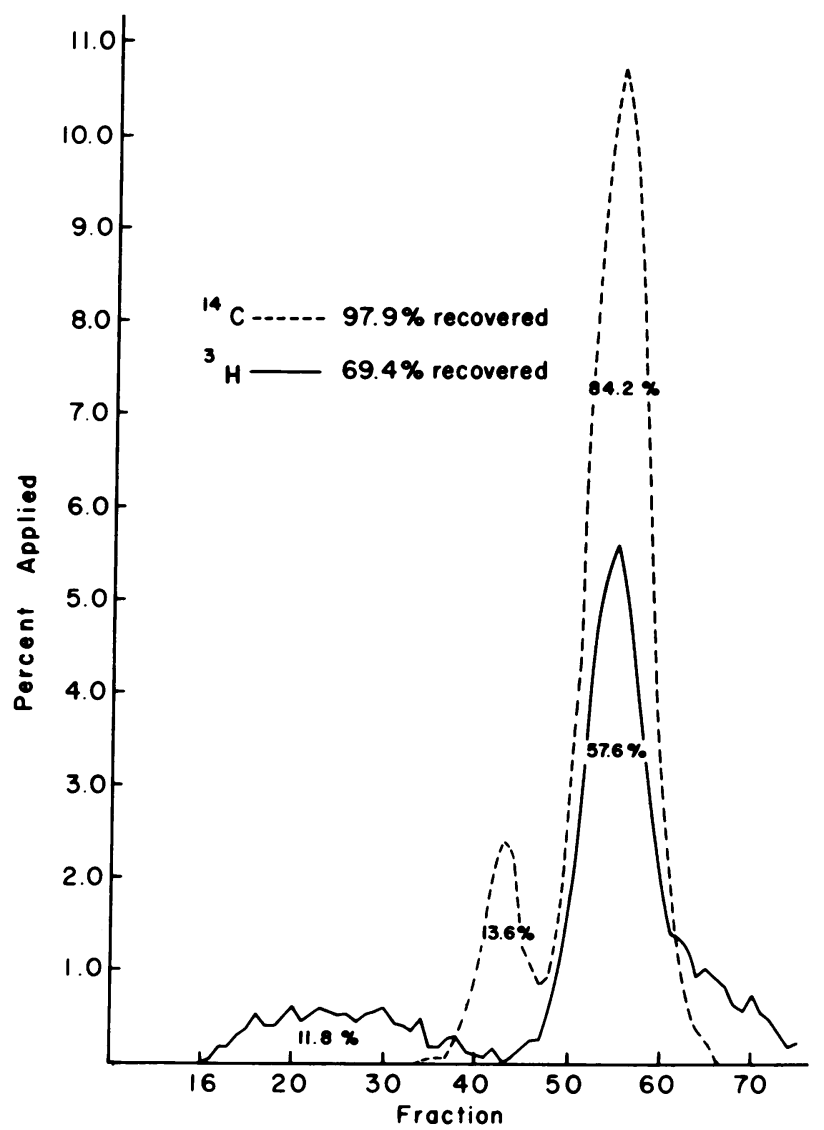

FIGURE 5 Co-chromatography of suspected $\left[{ }^{3} \mathrm{H}\right] 25-\mathrm{OH}-\mathrm{D}_{8}$ with $\left[{ }^{14} \mathrm{C}\right] 25-\mathrm{OH}-\mathrm{D}_{3}$ on hydroxyalkoxypropyl Sephadex columns. Vitamin D-deficient rats were hepatectomized and given an intrajugular dose of either $10 \mathrm{IU}(650 \mathrm{pmol})$ or 6.5 IU $(422.5 \mathrm{pmol})$ of $\left[1,2-{ }^{8} \mathrm{H}\right]$ vitamin $\mathrm{D}_{3}$. The tritium from the 25-OH-D region of the Sephadex LH-20 chromatographic profiles of the plasma extracted after $6 \mathrm{~h}$ was mixed with approximately the same number of counts of $\left[{ }^{14} \mathrm{C}\right] 25-\mathrm{OH}-\mathrm{D}_{3}$ and co-chromatographed.

25-OH-Ds-like material, an even smaller portion of this material is accumulated in the kidney and small intestine, and no $1,25-(\mathrm{OH})_{2} \mathrm{D}_{2}$-like material could be detected in any of the tissue extracts. Thus, any extrahepatic $25-\mathrm{OH}-\mathrm{D}_{3}$ made in these rats would appear to be of limited functional importance, inasmuch as $25-\mathrm{OH}-\mathrm{D}_{3}$ must be converted to $1,25-(\mathrm{OH})_{2} \mathrm{D}_{3}$ in the kidney before it can fulfill its physiological roles.

The rather unhealthy condition of hepatectomized rats may draw the criticism that this condition may inhibit extrahepatic 25-hydroxylation. This criticism is difficult to avert by any feasible technique. However, in support of the hepatectomy experiments, little or no in vitro 25-hydroxylation of vitamin $\mathrm{D}_{3}$ by intestine and kidney $(9,23)$ has been observed in rats $(12,23)$. Fur- 
thermore, the hepatectomized rats survived for $12 \mathrm{~h}$, and it would appear that at least during the first few hours when significant 25 -hydroxylation should have occurred, the health criticism should be less valid.

The nature of the extrahepatic 25-hydroxylation is unknown. Since it is apparently inhibited by a predose of vitamin $\mathrm{D}_{3}$, it would appear to be similar to the hepatic microsomal 25-hydroxylation (11). However, at least some of it may be carried out by the same system which hydroxylates cholesterol and dihydrotachysterol (24).

Unfortunately, the precise physiological significance of the extrahepatic 25-hydroxylation cannot be firmly ascertained. The present study, however, strongly supports the major importance of the liver in the metabolism of vitamin $\mathrm{D}_{3}$ in general and 25-hydroxylation in particular at least in mammals.

\section{ACKNOWLEDGMENTS}

This work was supported by a grant from the National Institutes of Health No. AM-14881 and the Wisconsin Alumni Research Foundation.

\section{REFERENCES}

1. DeLuca, H. F. 1974. Vitamin D: the vitamin and the hormone. Fed. Proc. 33 : 2211-2219.

2. Kodicek, E. 1974. The story of vitamin D from vitamin to hormone. Lancet. I : 325-329.

3. Olson, E. B., Jr., and H. F. DeLuca. 1973. Vitamin D: metabolism and mechanism of action. World Rev. Nutr. Diet. 17 : 164-188.

4. Rosenstreich, S. J., C. Rich, and W. Volwiler. 1971. Deposition in and release of vitamin $\mathrm{D}_{3}$ from body fat: evidence for a storage site in the rat. J. Clin. Invest. 50: 679-687.

5. Ponchon, G., and H. F. DeLuca. 1969. The role of the liver in the metabolism of vitamin D. J. Clin. Invest. 48: $1273-1279$.

6. Ponchon, G., A. L. Kennan, and H. F. DeLuca. 1969. "Activation" of vitamin D by the liver. J. Clin. Invest. 48: 2032-2037.

7. Ponchon, G., and H. F. DeLuca. 1969. Metabolites of vitamin $\mathrm{D}_{3}$ and their biological activity. J. Nutr. 99: 157-167.

8. DeLuca, H. F. 1969. 25-Hydroxycholecalciferol. The probable metabolically active form of vitamin $\mathrm{D}_{3}$ : its identification and subcellular site of action. Arch. Intern. Med. $124: 442-450$
9. Horsting, M., and H. F. DeLuca. 1969. In vitro production of 25-hydroxycholecalciferol. Biochem. Biophys. Res. Commun. 36: 251-256.

10. Horsting, M., and H. F. DeLuca. 1970. Feed-back control of 25-hydroxycholecalciferol production. Fed. Proc. 29: 542. (Abstr.)

11. Bhattacharyya, M. H., and H. F. DeLuca. 1973. The regulation of rat liver calciferol-25-hydroxylase. J. Biol. Chem. 248: 2969-2973.

12. Tucker, G., III, R. E. Gagnon, and M. R. Haussler. 1973. Vitamin $\mathrm{D}_{3}-25$-hydroxylase: tissue occurrence and apparent lack of regulation. Arch. Biochem. Biophys. 155 : 47-57.

13. Bollman, J. L., and E. Van Hook. 1968. A simplified two-stage hepatectomy in the rat. J. Appl. Physiol. 24: 722-723.

14. Suda, T., H. F. DeLuca, and Y. Tanaka. 1970. Biological activity of 25-hydroxyergocalciferol in rats. J. Nutr. $100: 1049-1052$.

15. Neville, P. F., and H. F. DeLuca. 1966. The synthesis of $\left[1,2-{ }^{3} \mathrm{H}\right]$ vitamin $\mathrm{D}_{3}$ and the tissue localization of a $0.25 \mu \mathrm{g}$ (10 IU) dose per rat. Biochemistry. 5: 22012207.

16. Bligh, E. G., and W. J. Dyer. 1959. A rapid method of total lipid extraction and purification. Can. J. Biochem. Physiol. 37 : 911-917.

17. Lund, J., and H. F. DeLuca. 1966. Biologically active metabolite of vitamin $\mathrm{D}_{3}$ from bone, liver, and blood serum. J. Lipid Res. 7 : 739-744.

18. Holick, M. F., and H. F. DeLuca. 1971. A new chromatographic system for vitamin $\mathrm{D}_{3}$ and its metabolites: resolution of a new vitamin $\mathrm{D}_{3}$ metabolite. J. Lipid Res. 12: $460-465$.

19. Jones, G., H. K. Schnoes, and H. F. DeLuca. 1975. Isolation and identification of 1,25-dihydroxyvitamin $\mathrm{D}_{2}$. Biochemistry. 14 : 1250-1256.

20. Ellingboe, J., E. Nyström, and J. Sjövall. 1970. Liquidgel chromatography on lipophilic-hydrophobic Sephadex derivatives. J. Lipid Res. 11: 266-273.

21. Rikkers, H., and H. F. DeLuca. 1967. An in vivo study of the carrier proteins of ${ }^{8} \mathrm{H}$-vitamin $\mathrm{D}_{3}$ and $\mathrm{D}_{4}$ in rat serum. Am. J. Physiol. 213: 380-386.

22. Arnaud, S. B., R. S. Goldsmith, P. W. Lambert, and V. L. W. Go. 1975. 25-Hydroxyvitamin $D_{3}$ : evidence of an enterohepatic circulation in man. Proc. Soc. Exp. Biol. Med. 149: 570-572.

23. DeLuca, H. F., S. A. Holick, and M. F. Holick. 1976. The metabolism and function of $1 \alpha$-hydroxyvitamin $D_{3}$. In Calcified Tissue 1975. S. Pors Nielsen and E. Hjøorting-Hansen, editors. F.A.D.L. Publishing Company, Copenhagen. In press.

24. Bhattacharyya, M. H., and H. F. DeLuca. 1973. Comparative studies on the 25-hydroxylation of vitamin $\mathrm{D}_{3}$ and dihydrotachysterols. J. Biol. Chem. 248: 2974-2977. 